УАK 332.3: 504.064

С. М. Смирнова, к. геол. н., Аоцент (бвз) кафеАри управління земельними ресурсами

Чорноморський національний університет імені Петра Могили

ORCID ID: 0000-0001-9106-7435

B. М. Смирнов,

к. геол. н., керівник екологічної лабораторії

TOB "С3 "Океан"

ORCID ID: 0000-0003-3809-6098

B. О. Фромольс,

магістрант кафедри управління земельними ресурсами

Чорноморський національний університет імені Петра Могили

ORCID ID: 0000-0003-3015-4812

DOI: $10.32702 / 2306-6792.2019 .19 .17$

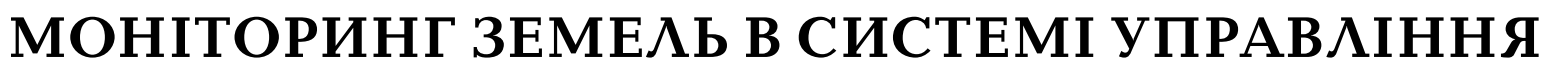 ЗЕМЕАЬНИМИ РЕСУРСАМИ
}

S. Smyrnova,

PhD in Geology, Associate Professor, Department of Land Management, Petro Mohyla Black Sea National University

V. Smyrnov,

$\mathrm{PhD}$ in Geology, head of the environmental laboratory Limited Liability Company "Ocean Shipyard"

V. Fromol's,

Master of the Department of Land Management, Petro Mohyla Black Sea National University

\section{LAND MONITORING IN THE LAND RESOURCE MANAGEMENT SYSTEM}

Статтю присвячено моніторингу земель як інструменту Аержавної політики у сфері охорони навколишнього природного середовища, яка дозволяє чітко визначити кількісні та якісні характеристики земельних ресурсів. Запропоновано алгоритм у сфері управління земельними ресурсами: постановка завдання, умови прийняття управлінських рішень, ситуативність, проблемність, елективність, організаційна чіткість, технологічна раціональність, методологія розробки рішення. Вказано на інтеграцію дійових заходів в сфері забезпечення високої ефективність землекористування у системі прийняття управлінських рішень на засадах моніторингу земель. Орієнтовано увагу на науково-організаційні засади розвитку Аержавної стратегї моніторингу земель у теоретичних засадах моніторингу земель, у законодавчій, містобудівній та нормативно-технічній діяльності, у земельному кадастрі та у сфері охорони земель. Запропоновано впровадження принципово нової методології моніторингу земель у контексті реалізації правової, цінової, санітарно-гігієнічної, історико-культурної, інженерно-геологічної діяльності.

The scientific basis of land monitoring in the land management system is an actual and effective instrument of public policy. Land monitoring (LM) implements the function of state management of land resources, the content of which is to monitor their condition and soil cover properties. Thus, agricultural land is intended for systematic observations that require the detection of the dynamics of processes related to soil fertility, deterioration of water-physical, physical-chemical indicators of soil, soil contamination with pesticides and heavy metals. The solution of the applied problems in the field of land management is based on the conscious needs of the decision, systematization of monitoring observations, situation analysis, expert assessment (diagnostics), development of a set of countermeasures and search for alternative management solutions for several options. Integration of actions into the system of management decisions based on land monitoring will ensure high efficiency of land use. The scientific and organizational bases for the development of the State Land Monitoring Strategy should include: improvement of methods, conditions for implementation of LM and accounting technologies. They also need to improve data collection, documentation, accounting, processing and storage technology through a comprehensive land survey. LM is aimed at solving urgent problems of land management in conditions of transition to multifaceted land use. For example, the solution of some applied issues requires detailing and unification of land management indicators, improvement of the methodology of land protection based on a comprehensive approach to their use, taking into account zonal and regional features; distribution of information support of the LM in the architectural and planning organization of urban and rural territories; land reclamation, which is used substantially to improve the methodological bases of cadastral and LM and real estate systems. It is advisable to introduce a fundamentally new methodology of LM in the context of the implementation of legal, price, sanitary-hygienic, historical-cultural, engineering-geological activities based on geodetic, geomorphological, geo-ecological, landscape approach.

Ключові слова: моніторинг земель, земельні ресурси, управління земельними ресурсами, контроль за використанням земель, земельні відносини.

Key words: land monitoring, land resources, land management, land use control, land relations.

\section{ПОСТАНОВКА ПРОБЛЕМИ}

В умовах реформування земельних відносин виникає потреба проведення моніторинг земель (M3), який виконує функцію інформаційно- аналітичного забезпечення державного управління земельними ресурсами (ЗР). Актуальність M3 посилюється у зв'язку з необхідністю завершення земельної реформи, яка передбачає 
докорінну перебудову земельних відносин, зміну структури земель та форм господарювання. Отже, сучасний стан використання ЗР України потребує системних повномасштабних моніторингових досліджень. Наразі тільки 41,6 млн га земель сільськогосподарського призначення потребують систематичних спостережень. Гостро постає питання моніторингу процесів, пов'язаних із змінами родючості грунтів (заболочення, засолення, розвиток дефляційних процесів, втрата гумусу, погіршення водно-фізичних, фізико-хімічних показників грунту), заростання земель сільськогосподарського призначення, забруднення земель пестицидами, важкими металами, радіонуклідами тощо). Саме ці тенденції грунтогенезу вимагають підвищеної уваги та визначають актуальність управлінських рішень у сфері керованих рішень 3Р, розробки науково-організаційних засад розвитку Аержавної стратегії моніторингу земель.

\section{АНАЛІЗ ОСТАННІХ ДОСЛІДЖЕНЬ І ПУБЛІКАЦІЙ}

Аналіз нормативно-правової бази дозволяє констатувати, що вперше МЗ було передбачене Земельним кодексом України, у редакції від 18.12.1990 р. Відповідно до Розділу V. "Контроль за використанням і охороною земель та їх моніторинг" М3 являє собою систему спостереження за станом земельного фонду, в тому числі земель, розташованих у зонах радіоактивного забруднення, з метою своєчасного виявлення змін, їх оцінки, відвернення та ліквідації наслідків негативних процесів (ст. 95) [1].

Значним кроком до формування змістовної державної політики у сфері управління ЗР є затверджено Постановою КМ України "Положення про моніторинг земель" від 20.08.1993 р. № 661 [2], з якого фактично почалися систематичні спостереження за станом 3Р. Визначено М3 як систему спостережень за станом земельного фонду з метою своєчасного виявлення змін, їх оцінки, відвернення й ліквідації наслідків негативних процесів.

Згідно із чинним законодавством України, об'єктом МЗ є весь земельний фонд країни незалежно від форм власності на землю і використання земель. МЗ передбачає ведення систематичних спостережень за станом усіх земель, виявлення змін у їх стані, а також оцінку: стану використання угідь, полів, ділянок; процесів, пов'язаних зі змінами родючості грунтів (розвиток водної і вітрової ерозії, втрата гумусу, погіршення структури грунту, заболочен- ня і засолення); заростання сільськогосподарських угідь, забруднення земель пестицидами, важкими металами, радіонуклідами та іншими токсичними речовинами; стану берегових ліній річок, морів, озер, заток, водосховищ, лиманів, гідротехніхних споруд; процесів, пов'язаних з утворенням ярів, зсувів, сельовими потоками, землетрусами, карстовими, кріогенними та іншими явищами; стану земель населених пунктів, територій, зайнятих нафтогазодобувними об'єктами, очисними спорудами, гноєсховищами, складами паливно-мастильних матеріалів, добрив, стоянками автотранспорту, захороненнями токсичних промислових відходів і радіоактивних матеріалів, а також іншими промисловими об'єктами [3].

Подальше державне регулювання та забезпечення розвитку системи моніторингу спрямоване на деталізацію дефініцій та розмежування повноважень. Так, з метою уникнення плутанини в поняттях зазначається, що моніторинг грунтів розглядається як складова частина МЗ і наступним кроком $€$ Наказ Мінагрополітики України "Про затвердження Положення про моніторинг грунтів на землях сільськогосподарського призначення" від 26.02 .04 р. № 51 [4]. Цей наказ має на меті реалізацію Законів України "Про охорону земель"[5], "Про державний контроль за використанням та охороною земель"[6].

Починаючи з 2015 р., в Україні запроваджено у форматі пілотного проекту перший Моніторинг земельних відносин, який був проведений Аержгеокадастром за підтримки Світового банку. Інформаційно-аналітичну підтримку здійснили шість відомств: Аержгеокадастру, Мін'юсту, Аержавної фіскальної служби, Аержстату, Аержводагентства, Аержавної судової адміністрації. Наступним кроком Кабінет міністрів України ухвалив Постанову "Про реалізацію пілотного проекту щодо проведення моніторингу земельних відносин та внесення змін до деяких постанов Кабінету Міністрів України" починаючи з 01.09.2017 р. Відповідно до цієї Постанови організацію проведення моніторингу здійснює Мінагрополітики, а відповідальними за його проведення є Аержгеокадастр та його територіальні органи за участю суб'єктів інформаційної взаємодії. Мета проведення: регулярний моніторинг ключових показників у сфері землекористування [7].

Розвиток системи МЗ став предметом дискусій серед науковців: Сохнич А.Я. [8] з співавторами аналізує земельний фонд України як об'єкт моніторингу та наводить критерії і нормативи для оцінки ерозійної небезпеки та еко- 
логічного стану земель в цілому; Панас Р.М. [9] висвітлює науково-теоретичні основи та методи прогнозування використання земель; Жулканич О.М. та Жулканич Н.О. [10] розглядають систематичний і системний М3 сільськогосподарського призначення, як одним 3 методів виявлення тенденцій динаміки і оцінки землекористування та наголошують на завданнях державного регулювання земельних відносин у процесі забезпечення раціонального використання земель сільськогосподарського призначення; Оверковська Т.К. [11] аналізує правові аспекти здійснення МЗ в Україні, виокремлює його завдання та перспективи удосконалення його проведення, звертає увага на особливості М3 сільськогосподарського призначення.

Незважаючи на наявність значної кількості наукових праць, проблема забезпечення державного управління земельними ресурсами на засадах МЗ залишається недостатньо дослідженою.

\section{ФОРМУЛЮВАННЯ ЦІЛЕЙ СТАТТІ}

Сучасні підході до управління земельними ресурсами вимагають наявності об'єктивної інформація про кількісний та якісний стан земель на засадах системних спостережень, що дозволить забезпечити сталий розвиток землекористування. Загострені питання сьогодення: 1) відсутність алгоритму формування управлінського рішення у сфері землекористування на засадах моніторингу земель; 2) відсутність науково-організаційних засад розвитку Аержавної стратегії моніторингу земель. Вирішення цих питань вимагає підвищеної уваги як 3 боку держави, так і науки.

\section{METOЮ СТАTTI}

Метою статті полягає в узагальнені наукових засад реалізації М3 у системі управління земельними ресурсами в умовах соціально-економічного та земельного реформування.

\section{ВИКЛАД ОСНОВНОГО МАТЕРІАЛУ ДОСЛІДЖЕННЯ}

Інформаційно-аналітичне забезпечення М3 безпосередньо впливає на процес державного управління земельними ресурсами. Постановка управлінського завдання включає усвідомлення потреби в рішенні, систематизація отриманих даних за наведеними проблематичними питаннями, аналіз ситуації, виявлення першопричин, експертну оцінку (діагностика), розробку комплексу протидій та пошук альтернатив - ось спрощений алгоритм приймання уп- равлінських рішень, які потрібно вирішувати, спираючись на отримані дані М3.

Результативною складовою є впровадження рішення на державних та громадських ініціативах. Наприклад, запровадження широкомасштабного використання грунтозахисних технологій, серед яких достатньо розвинута систему нульового обробітку грунту, відома в світі як No-till. Ця технологія дозволяє зменшити витрати родючого шару грунтів від ерозії, що виноситься вітром 3 рівнинних степів. Аргентинський досвід за останні 35 років дозволяє підсумувати про збільшення валового збору врожаю у три рази [12]. Безумовно, впровадження новітніх технологій має супроводжуватися подальшим аналізом і контролем.

Розробка управлінських рішень у сфері керованих рішень 3Р орієнтована на базисну платформу, якою виступає М3, та потребує дотримання алгоритмічної послідовності у процесі реалізації (рис. 1):

1. Постановка завдання має на меті цілеспрямованість у вирішенні питання. Потреба в управлінському рішенні у сфері використання ЗР виникає тоді, коли проявляються протиріччя цілі і ситуації, а також виникає необхідність зміни ситуації в напрямі прийнятої мети. Успішність вирішення окремого питання характеризує вибір найкоротшого шляху в стратегії збалансованого використання земель. Саме тому першочергово звертаються до бази даних М3, яка $є$ систематизованим масивом показників стану грунтів за часовими та просторовими вимірами.

2. Умови прийняття управлінських рішень визначені на рівні одноосібних, колегіальних або колективних рішень. Аля прийняття ефективних управлінських рішень у вирішенні питань управління 3Р необхідно дотримуватися таких умов:

- право прийняття рішення - окреслює сферу діяльності конкретних посадових осіб щодо прийняття відповідних рішень;

- повноваження управлінців - визначені посадовими обов'язками;

- обов'язковість зумовлена здатністю об'єктивно усвідомлювати необхідність прийняття рішення відповідно до ситуації, що склалася;

- компетентність - здатність приймати кваліфіковані, обгрунтовані рішення, адекватні реаліям;

- відповідальність з позиції управлінських рішень визначає міра осуду у разі невиконання функцій і зобов'язань, повноважень і очікувань. 
3. Ситуативність. Глибокий аналіз і розуміння ситуації сприяють реалізації рішень, які враховують характер і особливості ситуації, потреби її зміни. Результативність прийнятого рішення безпосередньо залежить від оцінки ситуації, розуміння всіх протиріч, закладених у ній, і всіх можливостей эї зміни. Рішення це усунення протиріч в існуючій ситуації. У цьому сенс і призначення рішення, цим визначається і його потенціал.

4. Проблемність. Рішення завжди повинне дозволяти будь-яку проблему, задля вирішення якої потрібно використовувати методи оцінювання ситуації. Аоцільно використовувати методи вибору альтернатив в умовах визначеності та невизаченості, методи багатокритеріальної оцінки, експертні методи тощо.

5. Елективність (від лат. вибраний, добірний) дозволяє реалізувати вибір одного варіанта 3 багатьох можливих (альтернативних). Як правило, у реальній практиці управління ЗР рідко буває одне-єдине рішення. Множинність існуючих можливих варіантів дозволяє оперувати ефективністю залежно від прийняття певного рішення. Отже, на підставі критеріального визначення комплексу показників грунту приймається елективне прийнятне рішення, яке враховує репрезентативність та якість. Так, якісний стан грунту, наданий за результатами моніторингових досліджень, передбачає планомірність техніко-економічного обгрунтування використання та охорони земель, розробку проектів організації використання земель.

6. Організаційна чіткість полягає у координації зусиль керівних структур, які працюють на досягнення спільної мети. Важлива наявність організаційного потенціалу в рішенні, організуючої сили. Рішення по суті своїй - це дія, яку не можливо здійснити без організації, тобто необхідного порядку, узгодження, розподілу зусиль, відповідальності тощо. Організаційна чіткість у сфері М3 простежується на всіх ланках системного спостереження: періодичність відбору зразків грунту, методика виконання аналізів, групування даних, злагодженість дій по оптимізації антропогенного навантаження тощо.

7. Технологічна раціональність представлена у вигляді комплексу дій керованої системи управління земельними ресурсами, яка повинна оптимізувати витрати часу, людських і матеріальних ресурсів. Також прийнятна послідовність, аргументованість та логістика дій, комплекс технічних засобів. Сам термін "технологія" у землекористуванні є сукупністю методів (способів) поводження із земельними ре-

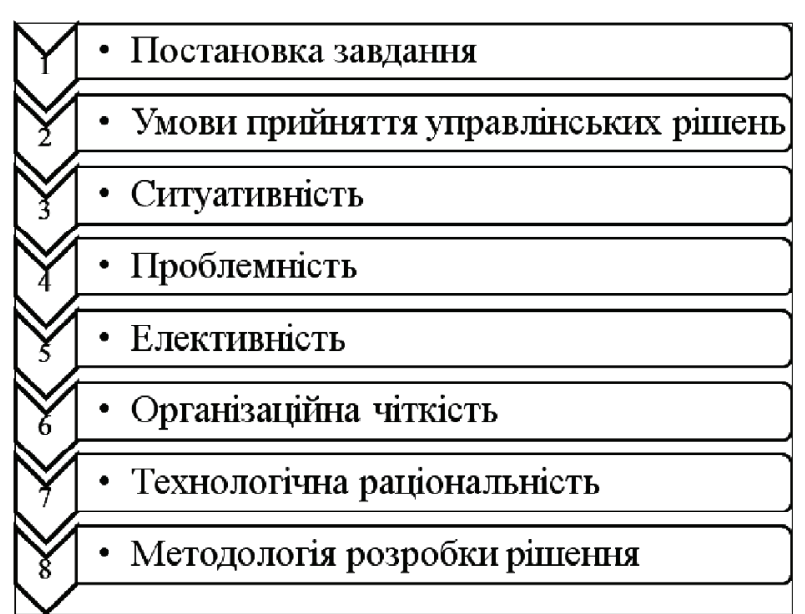

\section{Рис. 1. Алгоритм формування управлінського рішення у сфері землекористування на засадах моніторингу земель}

сурсами у процесі отримання продукції із заданими показниками якості. Розрізняють такі технології:

- стале землекористування - використання земель, що визначається тривалим користуванням земельною ділянкою без зміни їі цільового призначення, погіршення її якісних характеристик та забезпечує оптимальні параметри екологічних і соціально-економічних функцій територій (Абзац дванадцятий статті 1 в редакції Закону України "Про землеустрій" № 497VIII від 02.06.2015);

- природоохоронне землекористування це об'єкт економічних, екологічних, та інших земельних відносин, що регулюється законодавством для створення природоохоронного режиму використання ЗР (заказник, урочище, біосферний заповідник тощо);

- раціональне землекористування на рівні сільськогосподарського підприємства - це земельна ділянка або масив, яка задовольняє природні і економічні умови задля забезпечення збалансованого й ефективного використання землі, трудових і матеріально-технічних ресурсів.

8. Методологія розробки рішення полягає у виборі та реалізації відповідного підходу до аналізу й оцінки ситуацій та повинна базуватися на певній стратегії, тактиці. Оперативну реалізацію того чи іншого метода орієнтована на дослідження й проектування варіантів, структурування інформації. Власно від керівної структури залежить, яку саме буде вибрано методологічну концепцію: наукову, прагматичну, емпіричну, з позицій математичного моделювання, організаційної поведінки або з урахуванням ризикологічних аспектів тощо. Спро- 
щення вибору можливе за умови використання розгалуженої класифікації підходів до розробки управлінських рішень у сфері землекористування. Aле практика доводить, що вибір методології розробки рішення у сфері землекористування складається з їхньої комбінації, в якій завжди існують певні пріоритети.

Запропонований алгоритм дійових заходів у системі прийняття управлінських рішень на засадах M3 не можна розглядати відокремлено, оскільки лише їх інтеграція забезпечить високу ефективність у галузі землекористування.

Отже, спираючись на алгоритм формування управлінського рішення, виникає нагальна потреба розробити науково-організаційні засади розвитку Аержавної стратегії моніторингу земель у таких галузях:

I. Теоретичні основи моніторингу земель:

- актуальні проблеми природокористування;

- умови реалізації М3 в Україні;

- принципові положення М3.

II. Законодавча діяльність:

- закріплення на законодавчому рівні вимог до землевласників (землекористувачів) розробки та реалізації проектів рекультивації земель за результатами їх екстенсивного використання.

III. Нормативно-технічна діяльність:

- удосконалення методів і технологій обліку, збирання, документування, реєстрації, обробки та зберігання відомостей комплексного обстеження земель;

- деталізація та уніфікація показників контролю стану земель;

- доопрацювання системи контрольованих показників і мережі об'єктів спостереження за станом земель.

IV. Земельний кадастр:

- удосконалення методологічних основ систем кадастру та M3 і нерухомості в умовах переходу до багатоукладного землекористування;

- дослідження організаційно-правових форм землекористування та землеволодіння.

V. Містобудівна діяльність:

- поширена реалізація інформаційного забезпечення M3 в архітектурно-планувальній організації міської та сельбищної території;

- покращення наукових засад оцінки містобудівної та споживчої якості земель населених пунктів з урахуванням кадастрового зонування територій.

VI. Охорона земель:

- удосконалення методології охорони земель на основі комплексного підходу до їх ви- користання з врахуванням зональних і регіональних особливостей.

На нашу думку, доцільним є впровадження принципово нової методології МЗ у контексті реалізації правової, ціновӧ̈, санітарно-гігієнічної, історико-культурної, інженерно-геологічної діяльності на засадах геодезичного, геоморфологічного, геоекологічного, ландшафтного підходу.

\section{ВИСНОВКИ}

3 огляду на зростаюче антропогенне навантаження на земельні ресурси, виникає необхідність визнати моніторинг земель дієвим інструментом державної політики у сфері управління земельними ресурсами. Отримання інформації для вироблення рішень - основна мета моніторингу грунтів, яка спрямована на стабілізацію і якісне їх поліпшення, екологізацію землеробства. Прогноз використання земель на перспективу грунтується на аргументованих наукових передбаченнях, основою яких є системні спостереження за грунтами.

Запропоновані науково-організаційні засади розвитку Аержавної стратегії моніторингу земель орієнтовані на формування певних управлінських завдань у розвитку теоретичних засадах моніторингу земель, у інформаційному забезпечені земельного кадастру, а також законодавчої, містобудівної, охоронної та нормативно-технічній діяльності. 3 одного боку, моніторинг земель значною мірою впливає на зміст управлінських рішень, а з іншого - може розвиватися за умови вдосконалення алгоритму формування стратегії менеджменту земель. Постійне відстеження ситуації, обробка отриманої інформації і вироблення своєчасних коригувальних впливів - неодмінна умова функціонування моніторингу земель, яка супроводить систему управління земельними ресурсами.

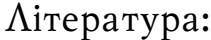

1. Земельним кодексом України: Постанова ВР України N 562-XII від 18 груд. 1990 р. URL: https://zakon.rada.gov.ua/laws/show/561-12 (дата звернення: 20.09.2019).

2. Положення про моніторинг земель: Постанова Кабінету Міністрів України від 20 серп. 1993 р. № 661. Земельне Право України. 1994. № 1. Ст. 5. URL: https://zakon.rada.gov.ua/laws/ show/661-93-\%D0\%BF (дата звернення: 18.09.2019).

3 Моніторинг земель // Юридична енциклопедія: [у 6 т.] / ред. кол. Ю. С. Шемшученко (відп. ред.) [та ін.] - К.: Українська енцикло- 
педія ім. М. П. Бажана, 2001. - Т. 3: К - М. 792 с. - ISBN 966-7492-03-6.

4. Положення про моніторинг грунтів на землях сільськогосподарського призначення: Наказ Мінагрополітики України від 26.02.04 р. № 51. URL: https://zakon.rada.gov.ua/laws/ show/z0383-04 (дата звернення: 19.09.2019).

5. Про охорону земель: Закон України від 19 червня 2003 р. № 962-IV / Верховна Рада України. Відомості Верховної Ради України. 2003. № 39. Ст. 349. URL: https://zakon.rada.gov.ua/laws/show/962-15 (дата звернення: 19.09.2019).

6. Про державний контроль за використанням та охороною земель: Закон України від 19 чер. 2003 р. № 963-IV: Верховна Рада України. Відомості Верховної Ради України. 2003. № 39. Ст. 350. URL: https://zakon.rada.gov.ua/ laws/show/963-15 (дата звернення: 18.09.2019).

7. Земля як товар: що нам дасть моніторинг земельних відносин. 24 канал: портал, URL: https://24tv.ua/ukrayina_tag1119/ (дата звернення: 18.09.2019).

8. Сохнич А.Я. Моніторинг земель: підручник / А.Я. Сохнич, М.С. Богіра, В.В. Горлачук, A.I. Солярчук, I.M. Песчанська; АН вищ. шк. України, Акад. екон. наук України, Міжнар. акад. наук екол. і безпеки життєдіяльн., $\Lambda$ ьвів. нац. аграр. ун-т. -.$:$ Манускрипт, 2008. - 263 с.

9. Панас Р.М. Основи моніторингу та прогнозування використання земель: навч. посіб. / Р.М. Панас; Нац. ун-т " $\Lambda$ ьвів. політехніка". -

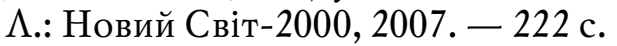

10. Жулканич О.М. Моніторинг земель сільськогосподарського призначення в системі аграрного природокористування / О.М. Жулканич, Н.О. Жулканич // Науковий вісник Ужгородського університету. Серія: Економіка. 2014. - Вип. 2. - С. 74-77. URL: http:// nbuv.gov.ua/UJRN/Nvuuec_2014_2_16 (дата звернення: 18.09.2019).

11. Оверковська Т.К. Моніторинг земель України: правові аспекти / Т.К. Оверковська // Юридичний вісник. Повітряне і космічне право. - 2015. - № 1. - C. 125-128. URL: http:// nbuv.gov.ua/UJRN/Npnau_2015_1_25 (дата звернення: 19.09.2019).

12. В Україні впроваджуватимуть no-till за аргентинським досвідом. GrowHow/in/ua: вебсайт. URL: https://www.growhow.in.ua/vukrayini-vprovadzhuvatymut-no-till-za-argentynskym-dosvidom/ (дата звернення: 20.09.2019).

\section{References:}

1. The Verkhovna Rada of Ukraine (1990), "Land Code of Ukraine, available at: http:// zakon.rada.gov.ua/laws/show/2768-3 (Accessed 20 September 2019).

2. Cabinet of Ministers of Ukraine (1993), "Regulations on land monitoring", Zemel'ne Pravo Ukrainy, vol. 1. article 5, available at: https:// zakon.rada.gov.ua/laws/show/661-93-\%D0\%BF (Accessed 18 September 2019) [in Ukrainian].

3. Shemshuchenko, Yu. S. (2001), "Land monitoring", Yurydychna entsyklopediia [Legal Encyclopedia], Ukrains'ka entsyklopediia im. M. P. Bazhana, Kyiv, Ukraine.

4. Ministry of Agrarian Policy of Ukraine (2004), The Order "Regulations on soil monitoring on agricultural lands", available at: https:// zakon.rada.gov.ua/laws/show/z0383-04. (Accessed 19 September 2019).

5. The Verkhovna Rada of Ukraine (2003), The Law of Ukraine "About the protection of land", available at: https://zakon.rada.gov.ua/laws/ show/962-15 (Accessed 19 September 2019).

6. The Verkhovna Rada of Ukraine (2003), The Law of Ukraine "On state control over land use and protection", available at: https://zakon.rada.gov.ua/laws/show/963-15 (Accessed 18 September 2019).

7. Portal 24 channel (2019), "Land as a commodity: what will enable us to monitor land relations", available at: https://24tv.ua/ukrayina_tag1119/ (Accessed 18 September 2019).

8. Sokhnych, A.Ya. Bohira, M.S. Horlachuk, V.V.Soliarchuk, D.I. and Peschans'ka, I.M. (2008), Monitorynh zemel' [Land monitoring], Manuskrypt, L'viv, Ukraine.

9. Panas, R. M. (2007), Osnovy monitorynhu ta prohnozuvannia vykorystannia zemel' [Basics of land use monitoring and forecasting], Novyj Svit2000, L'viv, Ukraine.

10. Zhulkanych, O.M. and Zhulkanych, N.O. (2014), "Monitoring of agricultural lands in the system of agrarian nature management", Naukovyj visnyk Uzhhorods'koho universytetu. Seriia: Ekonomika, vol. 2, pp. 74-77, available at: http:/ /nbuv.gov.ua/UJRN/Nvuuec_2014_2_16 (Accessed 18 September 2019).

11. Overkovs'ka T.K. (2015), "Land monitoring in Ukraine: legal aspects", Yurydychnyj visnyk. Povitriane i kosmichne pravo, vol. 1, pp. 125-128, available at: http://nbuv.gov.ua/UJRN/Npnau_2015_1_25 (Accessed 19 September 2019).

12. GrowHow.in.ua (2019), "In Ukraine, they will introduce no-till according to Argentine experience", available at: https://www.growhow.in.ua/v-ukrayini-vprovadzhuvatymut-no-till-zaargentynskym-dosvidom/ (Accessed 20 September 2019).

Стаття надійшла до редакиї̈ 01.10.2019 р. 